\title{
Kontinentale spaendinger - matematiske modeller leverer ny viden
}

Af (adjunkt) David Lundbek Hansen og (lektor) Søren Bom Nielsen, Geologisk Institut, Aarhus Universitet

Indtil nu har geologer antaget, at hævningsfaserne i de sedimentære bassiner var ledsaget af en samtidig øget tektonisk aktivitet ved pladeranden, men nye computersimulationer har nu vist, at bassinerne også hæves, når den tektoniske aktivitet er på retur.

Den europæiske kontinentalplade har siden kollisionen med den afrikanske kontinentalplade begyndte i Kridttiden, hovedsageligt været $i$ en tilstand af kompression (sammenpresning). Pyrenæerne, Alperne og Dinariderne er bjergkæder dannet tæt på den europæiske kontinentalplades rand som følge heraf.

Men også i kontinentalpladens indre, langt fra randen, har sammenstødet sat sine spor. Her var det primært de sedimentære bassiner som blev udsat for hævning og efterfølgende erosion, da pladens rand blev påvirket af kompressive spændinger. De sedimentære bassiner, som findes spredt ud over den europæiske plade, fungerer nemlig som kontinentalpladens svage "buffer-zoner" og i dem vil enhver større ændring af spændingsfeltet ved pladens rand kunne registreres. Ved at studere bassinernes deformationshistorie er det altså omvendt muligt at opnå viden om effekten og timin-

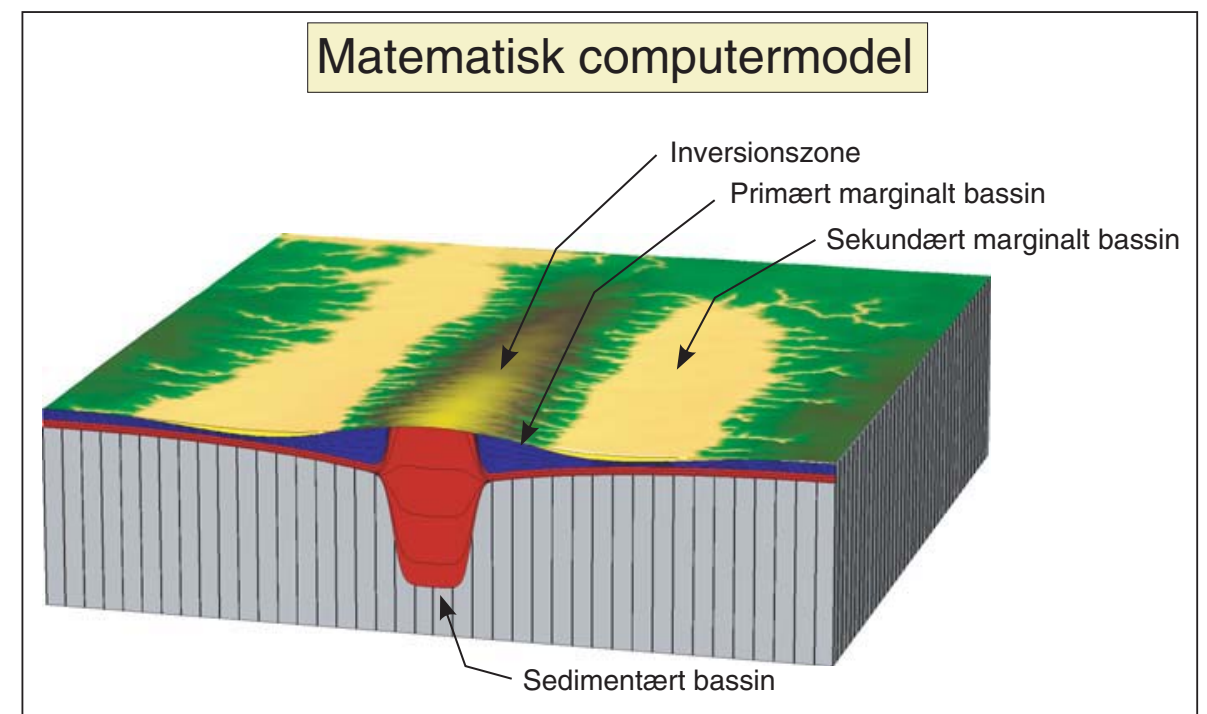

Udsnit af matematisk computermodel. Figuren viser lithosfarens øverste del med et inverteret sedimentart bassin. Modellen er vist, som den ser ud lige efter inversionens sekundare fase. På modellens overflade eroderes den bløde topografi, mens floder og vandløb (fluviale netvark) sørger for at fordele det eroderede sediment. (Grafik: Forfatterne)

gen af de tektoniske processer nær kontinentalpladens rand.

Hidtil har geologer ment, at enhver hævningsfase i de sedimentære bassiner er tegn på samtidig øget tektonisk aktivitet ved pladens rand. Men matematiske computermodeller har nu afsløret, at sedimentære bassiner også hæves, når den tektoniske aktivitet aftager og spændingerne mindskes

Denne nye viden, som i foråret blev publiceret i tidsskriftet "Nature", tvinger geologerne til at nytolke de sedimentære bassiners

\section{Matematiske modeller}

Brugen af geodynamiske, matematiske modeller har taget fart i takt med, at større og hurtigere computere er blevet tilgængelige. Modellerne er baseret på veletablerede fysiske principper som $\mathrm{fx}$ Newtons love eller termodynamikkens regler. Ofte inddrages viden fra forskellige fag som fysik, geologi og kemi, ligesom der typisk trækkes på erfaringer fra ingeniørkunsten.

De matematiske modeller kan benyttes på flere forskellige måder. Ind imellem ønsker man blot at samle allerede etableret viden i en overskuelig og pædagogisk præ- sentation, som for eksempel en computeranimation, men mere interessant er det, når modellerne anvendes direkte i videnskabelig sammenhæng. Her er det nødvendigt at bringe modellerne i spil på en sådan måde, at de bidrager med ny viden. Eller sagt med andre ord, at mere information kommer ud af modellerne, end man putter ind i dem.

Det sidstnævnte er ofte den største udfordring for modelløren, men at det kan lykkes, er historien om bassininversion og det palæocæne spændingsfelt et godt eksempel på. signaler. Allerede nu står det klart, at de hidtidige teorier om den europæiske plades spændingsfelt siden Kridt må revideres.

\section{Inversion af sedimentære bassiner} Et område som gennem geologisk tid har oplevet indsynkning, og hvori store mængder sedimentært materiale er aflejret, betegnes et "sedimentært bassin". Ofte er et sedimentært bassin opstået gennem strækning og fortynding af den underliggende lithosfære, hvorved overfladen synker og danner plads til aflejringer. Mængden af sediment måles her typisk på kilometer-skala, og indsynkningsperioderne kan samlet være meget lange (> 50 mio. år).

I mange sedimentære bassiner ses desuden spor efter perioder, hvori området midlertidigt har oplevet hævning. I en sådan hævningsperiode eroderes dele af det tidligere aflejrede sediment, og man siger at bassinet "inverterer". Hævnings- og indsynkningsperioderne kan dateres ved nøje at kortlægge de forskellige aflejringers rumlige og tidslige udbredelse. Dette arbejde baseres på store mængder data indsamlet bl.a. ved hjælp af seismiske metoder, borehulslogging samt biostratigrafisk datering af kerneprøver ved hjælp af mikrofossiler. I Europa er der tale om to vigtige perioder hvori de fleste sedimentære bassiner samtidigt blev udsat for inversion; den første i sen Kridt (80 - 65 
mio. år) og den anden i midt Paleocæn ( $\sim 60$ mio. år).

På grund af aflejringerne leverer de sedimentære bassiner uundværlig information om kontinentalpladernes tektoniske historie. For at forstå de sedimentære bassiners signaler om indsynkning og hævning i detalje, kræves kendskab til bassin-områdernes mekanik.

Det er nødvendigt at vide nøjagtigt hvad der forårsager hævning, og hvad der forårsager indsynkning. Hidtil har man forklaret hævningsperioderne (både den i sen Kridt og den i midt Paleocæn) med kompression; altså en sammenpresning af lithosfæren under de sedimentære bassiner. Omvendt har indsynkning været tilskrevet strækning og fortynding.

De matematiske modeller har imidlertid afsløret, at bassinernes mekaniske opførsel er mere kompliceret end som så. Modellerne forudsiger nemlig, at fænomenet bassininversion er opdelt $i$ to forskellige faser. Den første inversionsfase er ganske rigtigt forbundet med kompression og fortykning af lithosfæren, gennem bl.a. reaktivering af gamle normalforkastninger i overskydninger. Men den anden og nyligt opdagede fase er derimod relateret til afslapning af de eksisterende kompressive spændinger i bassinet, og er ikke associeret med betydelig

forkastningsaktivitet. De to inversionsfaser er forbundne, og vi taler nu om den primære og den sekundære inversionsfase.

Lithosfærens stivhed, og dens evne til at "bøje" som et elastisk lag, er af central betydning for mekanismen bag inversionsfænomenet. Når et sedimentært bassin sammenpresses i den primære inversionsfase, deformerer skorpen under sedimenterne vha. forkastninger. Skorpen fortykkes derved og sedimenter løftes op over havoverfladen, hvor de udsættes for erosion. Derudover belaster den fortykkede skorpe

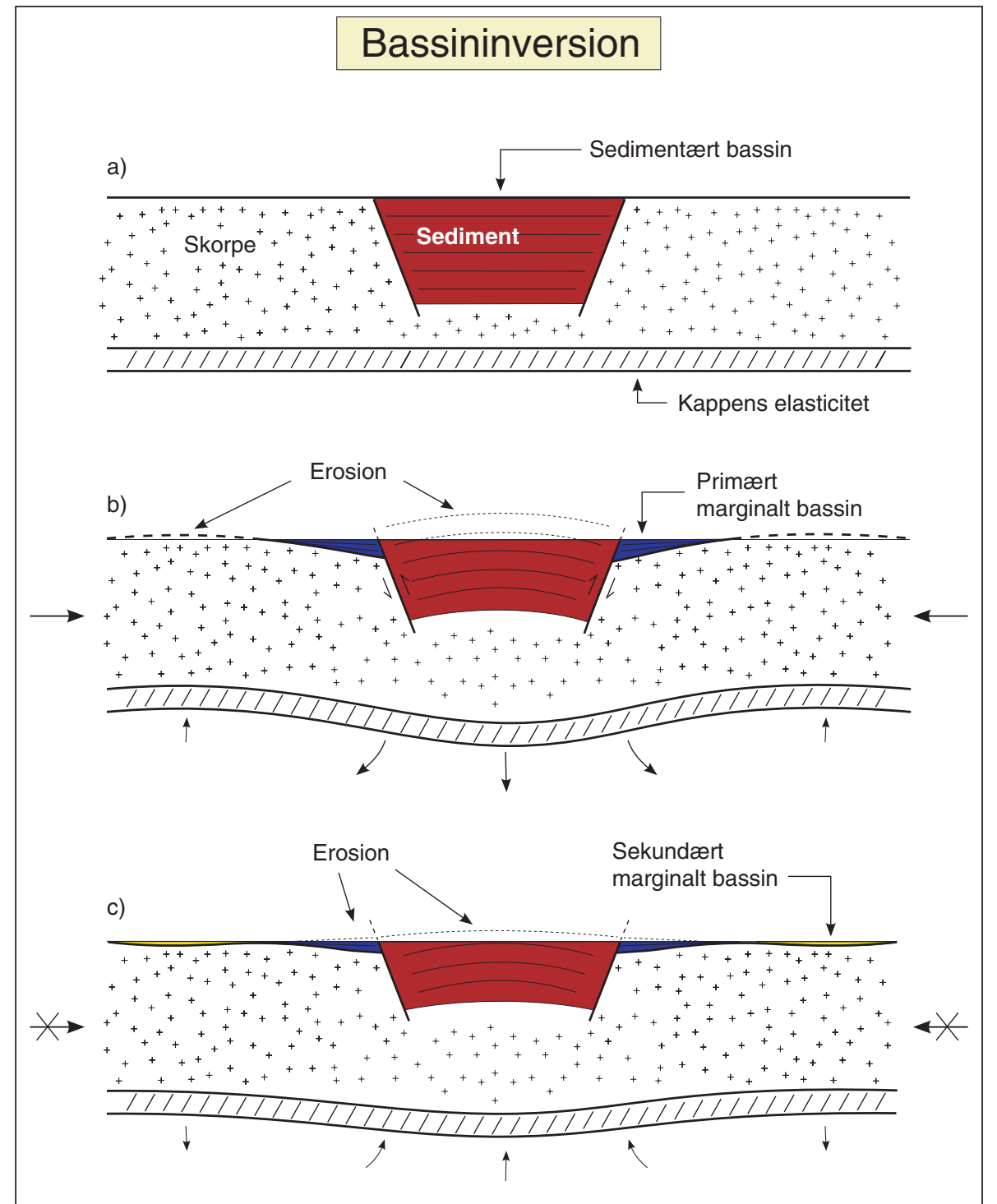

Mekanismen bag bassininversion er her illustreret vha. en skitse. a) Bassinet før inversion, b) efter den primare fase og c) efter den sekundcere fase. Kappens elasticitet er reprosenteret ved en tynd elastisk plade (skraveret område), som bøjer under vertikalt og horisontalt tryk. De matematiske modeller opererer dog med en mere kompliceret nedre skorpe- og kappe-mekanik, idet duktil krypning såvel som plastiske brud og opdriftskrcefter tages i betragtning. De horisontale pile $i b)$ indikerer det kompressive spandingsfelt, som driver den primare inversionsfase. I c) fjernes spandingsfeltet. Skorpen er typisk omkring 35-40 km tyk under et bassin med ca. $6 \mathrm{~km}$ sedimenter. (Grafik: Forfatterne)

den underliggende øverste kappe, som udgør lithosfærens stærkeste og mest elastiske del. Kappen synker under skorpens forøgede vægt, men pga. kappens elasticitet er indsynkningen udbredt, og der dannes plads til såkaldte primære marginale bassiner ved flankerne af det fortykkede bassinområde. De primære marginale sediment-bassiner er let genkendelige ved at de bliver dybere ind mod den inverterede zone. De flankerer langt de fleste sedimentære bassiner på den europæiske kontinentalplade og er hovedsageligt fyldt med kridt; et tegn på at inversionsperioden i sen-Kridt udgør den primære inversionsfase.

De primære marginale bassiner er således et direkte signal om, at lithosfærens elastiske del er nedbøjet pga. vægten fra den fortykkede skorpe under det inverterede sedimentære bassin. Nedbøjningen bliver yderligere forstærket af de horisontale kompressive spændinger, der driver den primære inversionsfase. Man skal her forstille sig, at det inverterede bassin bliver fastholdt i en ligevægtssituation, hvor kappens nedbøjning er en smule større end den ville være, hvis bassinet ikke blev trykket på. Hvis de horisontale spændinger nu reduceres eller helt forsvinder, vil bassinet søge mod en ny ligevægtstilstand med mindre kappenedbøjning. Denne ændring i bassinets ligevægtstilstand er den nyopdagede sekundære inversionsfase. Under denne ændring hæves bassinets centrale dele igen, men som en blød bakke uden betydelig forkastningsaktivitet. Topografien er således blød og af regional karakter, i modsætning til topografien under den primære inversionsfase, hvor bassinets hævning er styret af få afgrænsede forkastninger. Som under den primære inversionsfase opstår der også marginale bassiner - de sekundære marginale bassiner 


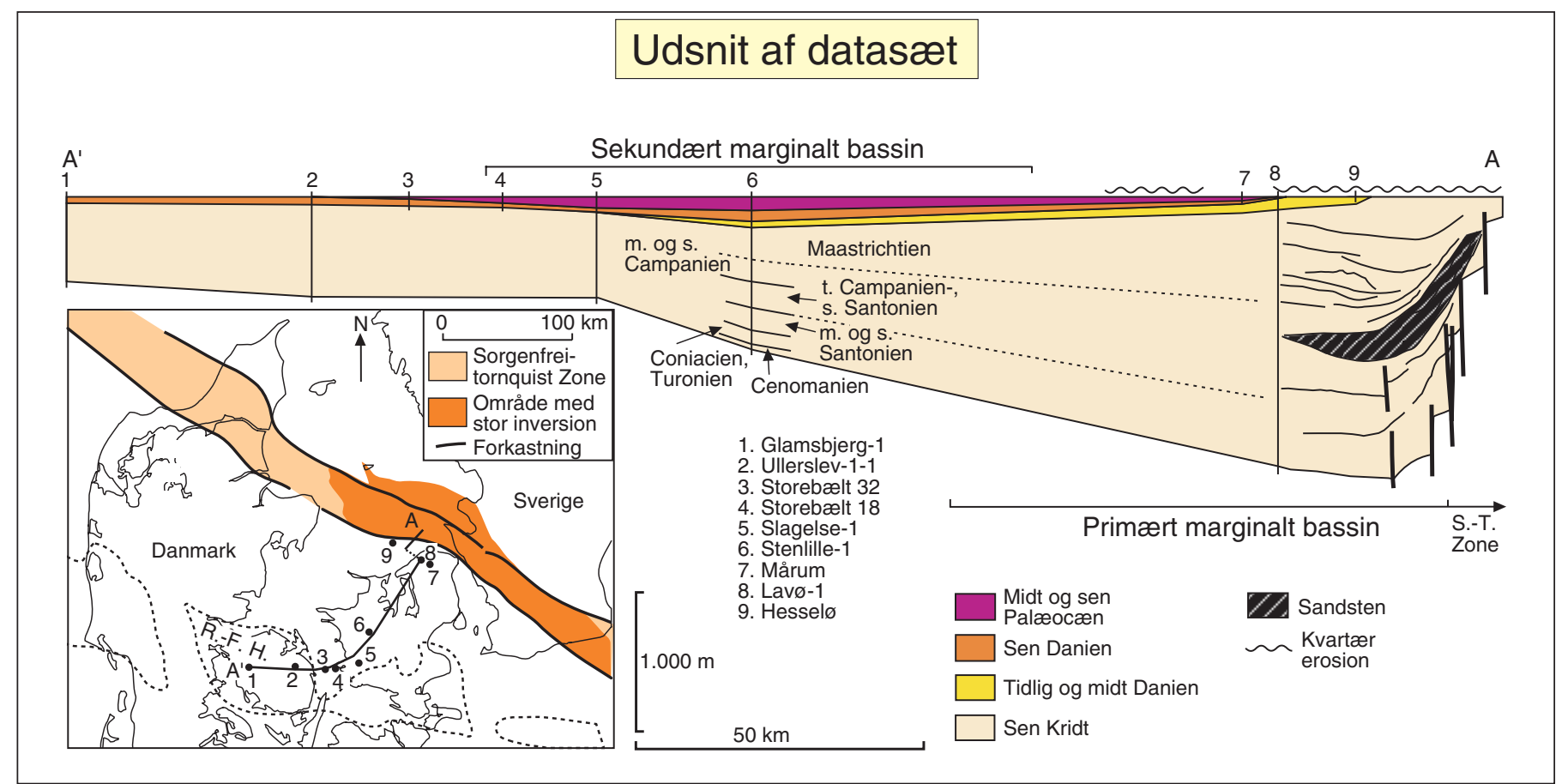

Udsnit af datasattet fra det danske område. Det seismiske profil starter på Fyn og ender lige syd-vest for den inverterede Sorgenfrei-Tornquist Zone og dcekker altså området syd-vest for en inversionszone. På profilet ses både et primcert marginalt bassin, med op til 2 km sen-Kridt aflejringer, og et sekundart med aflejringer fra Danien og Paleocan. (Grafik: lektor Erik Thomsen, Geologisk Institut, Aarhus Universitet)

- som dog er mere symmetriske og mindre dybe end de primære marginale bassiner.

\section{Data bl.a. fra det danske område}

Den sekundære inversionsfase blev som nævnt opdaget ved brugen af computermodeller, og det skete ved lidt af et tilfælde. Modellerne var designet til at beregne effekten af at sammentrykke et sedimentært bassin og skulle altså levere en realistisk simulering af den primære inversionsfase. Herigennem fik man bl.a. styr på sammenhængen mellem hævningen af selve inversionszonen og de primære marginale bassiner.

Men som en sidegevinst viste modellerne, at der teoretisk set burde eksistere en sekundær inversionsfase, som ingen dog kendte til. Grundige studier af data fra inversionszonerne skulle nu afsløre, om modellerne var rigtige i deres forudsigelse.
Et vigtigt datasæt fra det danske område blev leveret af lektor Erik Thomsen (Geologisk Institut, Aarhus Universitet). Det bestod af geologiske profiler samt nøje daterede kerneprøver fra boringer sydvest for den inverterede Sorgenfrei-Tornquist Zone. Her blev det hurtigt klart, at områdets vertikale bevægelser i midt-Paleocæn passede forbavsende godt med modellernes forudsigelser af den sekundære inversionsfase. Den bløde hævning og resulterende erosion kan ses på de geologiske tværsnit, mens et sekundært marginalt bassin med paleocæne aflejringer findes på Sjælland og i Kattegat på lokaliteter som forudsagt af de matematiske modeller. Lektor Ole Rønø Clausen (Geologisk Institut, Aarhus Universitet) kunne supplere med lignende eksempler fra det danske og hollandske Nordsøområde. Yderligere data fra sedimentære bassiner i Polen, Tyskland,
Holland og det sydlige England bekræftede herefter endeligt at den sekundære inversionsfase var et generelt og samtidigt fænomen.

\section{Nytolkning}

Eksistensen af den sekundære inversionsfase er som sagt en ny erkendelse. Derfor er alle tegn på generelle inversionsperioder (i Europa både den i sen Kridt og den i midt Paleocæn) tidligere blevet forklaret med forøget tektonisk aktivitet ved pladens rand og opbygningen af kompressive horisontale spændinger, som det er tilfældet under den primære inversionsfase. De sedimentære bassiners "tektoniske signal" er dermed blevet delvist fejlfortolket.

Nu ved vi imidlertid at inversionsperioden i midt Paleocæn ikke var en selvstændig inversionsperiode, men derimod den sekundære inversionsfase efterfølgende den pri- 


\section{Lithosfaeren}

Lithosfæren udgør Jordens yderste stive

skal. Her antager bjergarter en fast form,

og varme transporteres primært gennem termisk ledning (varmeledning) i modsætning til den termiske konvektion (omrøring), som dominerer den underliggende flydende kappe.

Lithosfæren består af Jordens skorpe samt den yderste del af kappen. Dens tykkelse afhænger af termiske og mineralogiske forhold og varierer betydeligt. Således er lithosfæren tyndest under oceaner og ved midt-oceaniske rygge er den helt gennembrudt. Under kontinenter er lithosfæren tykkest $(>200 \mathrm{~km})$ i gamle

mære fase i sen Kridt. Dette har vidtgående konsekvenser for vores forståelse af den europæiske kontinentalplades spændingsfelt i midt Paleocæn. Modsat den primære inversionsfase, er den sekundære nemlig relateret til aftagende tektonisk aktivitet og aftagende horisontale spændinger, hvilket betyder, at kollisionen mellem Afrika og Europa snarere ophørte for en periode i Paleocæn, end at den accelererede som hidtil antaget.

Eller måske blev spændingernes retning ændret af begivenheder nær den europæiske plades nordvestlige rand, hvor Nordatlantens og kolde skjoldområder som det skandinaviske skjold, og tyndest $(\sim 100 \mathrm{~km})$ under sedimentære bassiner som Nordsø-bassinet.

Lithosfærens mekaniske styrke og egenskaber bestemmes bl.a. af temperatur, tryk og mineralogiske forhold, hvilket resulterer i en kompliceret lagdelt struktur med vekslende stærke og svage lag. Matematiske computermodeller er velegnede til at håndtere det komplicerede samspil mellem temperatur, tryk og mineralogi og har derfor bidraget betydeligt til vores forståelse af lithosfærens opførsel på geologiske tidsskalaer.

åbning tog fart. Under alle omstændigheder står det klart, at den europæiske kontinentalplades tektoniske historie stadig udfordrer os med uløste gåder. Gåder, som kendskabet til de sedimentære bassiners mekanik måske kan hjælpe til at løse.

\section{Litteratur:}

Nielsen, S.B., Thomsen, E., Hansen, D.L. \& Clausen, O.R., 2005: Plate-wide stress relaxation explains European Paleocene basin inversions. Nature, 435, n. 7039, p. 195-198. 